\title{
Synthesis of Some Cryptolepine Analogues, Assessment of Their Antimalarial and Cytotoxic Activities, and Consideration of Their Antimalarial Mode of Action
}

\author{
Onyeka Onyeibor, ${ }^{\dagger}$, Simon L. Croft, ${ }^{\S}$ Hilary I. Dodson,,$^{\prime}$ Mohammad Feiz-Haddad, ${ }^{\dagger}$ Howard Kendrick,, \\ Nicola J. Millington, ${ }^{\perp}$ Silvia Parapini, ${ }^{\#}$ Roger M. Phillips,${ }^{\perp}$ Scott Seville ${ }^{\dagger}$ Steven D. Shnyder, ${ }^{\perp}$ \\ Donatella Taramelli, ${ }^{*}$ and Colin W. Wright*,† \\ The School of Pharmacy, Department of Biomedical Sciences and Tom Connors Cancer Research Centre, University of \\ Bradford, West Yorkshire, BD7 1DP, U.K., Department of Infectious and Tropical Diseases, London School of Hygiene and \\ Tropical Medicine, Keppel Street, London, WC1E 7HT, U.K., and Instituto di Microbiologia, Universitá di Milano, \\ Via Pascal 36, 20133, Milano, Italy
}

Received November 3, 2004

A series of analogues of cryptolepine (1) have been synthesized and evaluated for their in vitro antiplasmodial and cytotoxic properties. The $\mathrm{IC}_{50}$ values of several compounds $(\mathbf{1 1 a}, \mathbf{1 1 k}-\mathbf{m}$, 11o, 13) against Plasmodium falciparum (strain K1) were $<0.1 \mu \mathrm{M}, 5-10$-fold lower than that of 1 but their cytotoxicities were only 2-4 times greater than that of $\mathbf{1}$. Compounds with a halogen in the quinoline ring and a halogen or a nitro group in the indole ring have enhanced antiplasmodial activity. In mice infected with $P$. berghei, the 7-bromo-2-chloro $(\mathbf{1 1 k})$ and 2-bromo-7-nitro (13) derivatives of 1 suppressed parasitemia by $>90 \%$ at doses of $25 \mathrm{mg} \mathrm{kg} \mathrm{g}^{-1}$ day $^{-1}$ with no apparent toxicity to the mice. 2,7-Dibromocryptolepine (15) was evaluated at several dose levels, and a dose-dependent suppression of parasitemia was seen $\left(\mathrm{ED}_{90}=21.6\right.$ $\mathrm{mg} \mathrm{kg}{ }^{-1}$ day $^{-1}$ ). The antimalarial mode of action of $\mathbf{1}$ appears to be similar to that of chloroquine and involves the inhibition of hemozoin formation. A number of analogues were assessed for their effects on the inhibition of $\beta$-hematin (hemozoin) formation, and the results were compared with their antiplasmodial activities having taken account of their predicted accumulation into the acidic parasite food vacuole. No correlation was seen $\left(r^{2}=0.0781\right)$ suggesting that the potent antimalarial activity of compounds such as $\mathbf{1 5}$ involves other mechanisms in addition to the inhibition of hemozoin formation.

\section{Introduction}

Recently, the urgent need for new agents to combat the growing problem of malaria caused by resistant strains of Plasmodium falciparum has been highlighted. ${ }^{1}$ Natural products, exemplified by quinine and artemisinin, have made an immense contribution to malaria treatment and have also served as lead compounds for the development of synthetic and semisynthetic antimalarials. The continued investigation of natural products, particularly those originating from plant species used in traditional medicines for the treatment of malaria may prove to be fruitful in the search for new drugs to treat this disease that currently claims the lives of up to 3 million people each year.

Cryptolepine (5-methyl-10H-indolo[3,2-b]quinoline) (1) is an indoloquinoline alkaloid present as the major

* Corresponding author. tel: +44 (0) 1274 234739; fax +44 (0) 1274 235600; e-mail: c.w.wright@bradford.ac.uk

$\dagger$ The School of Pharmacy, University of Bradford.

* Present address: Emzor Pharmaceutical Industries Ltd., Aswani Market Road, P.O. Box 52053, Ikoyi, Lagos, Nigeria.

$\S$ London School of Hygiene and Tropical Medicine.

" Department of Biomedical Sciences, University of Bradford.

$\perp$ Tom Connors Cancer Research Centre, University of Bradford.

\# Instituto di Microbiologia, University di Milano.

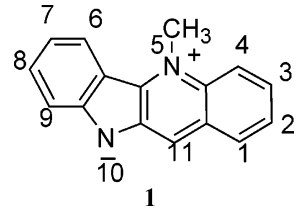

constituent in the roots of the West African climbing shrub Cryptolepis sanguinolenta (family Periplocaceae). A decoction of the roots of this species is used in traditional medicine for the treatment of malaria as well as for a number of other infectious and noninfectious diseases. ${ }^{2}$ Cryptolepine (1) has potent in vitro antiplasmodial activity ${ }^{3}$ but it is also cytotoxic on account of its abilities to intercalate into DNA and inhibit topoisomerase II as well as DNA synthesis. ${ }^{4,5}$ However, in a previous study, ${ }^{3}$ it was shown that the antiplasmodial action of $\mathbf{1}$ is due, at least in part, to a chloroquine-like action (inhibition of $\beta$-hematin formation) that does not depend on intercalation into DNA. Chloroquine (and related 4-aminoquinoline antimalarials) are believed to act primarily by binding to heme released following the digestion of hemoglobin in the host red blood cells, thus preventing the detoxification of heme. ${ }^{6}$ Normally, heme is detoxified by conversion into insoluble hemozoin (malaria pigment) that has been shown to be a dimer of 
heme and is identical to $\beta$-hematin ${ }^{7}$ (formed when hematin is incubated at $60{ }^{\circ} \mathrm{C}$ in $4.5 \mathrm{M}$ acetate buffer). ${ }^{8}$ The binding of chloroquine to heme prevents hemozoin formation, and the free heme or drug-heme complex is believed to exert a toxic effect on the parasite. ${ }^{6}$ However, this action is enhanced as a result of the accumulation of chloroquine into the acidic food vacuole of the malaria parasite, the site of hemoglobin digestion. ${ }^{6}$ Since $\mathbf{1}$, in common with chloroquine, is a weak base, it is possible that accumulation into the food vacuole and the inhibition of haemozoin formation are involved in its antiplasmodial mode of action.

In a previous study, the synthesis of a series of analogues of 1 was reported, and some of these were shown to have enhanced antiplasmodial activities in vitro against both chloroquine-sensitive and chloroquine-resistant strains of $P$. falciparum. ${ }^{3}$ Further, several compounds were found to have encouraging activity in mice infected with $P$. berghei, and importantly, in contrast to 1 , no apparent toxicity was seen in the mice. These results indicated that analogues of $\mathbf{1}$ have potential as lead compounds to new antimalarial agents.

In this paper we report the synthesis of a further 16 cryptolepine derivatives of which 11 are novel in order to gain additional information with respect to structureactivity relationships. Compounds were assessed for their in vitro antiplasmodial activities against $P$. falciparum (multidrug-resistant strain K1) and for cytotoxicity against MAC15A (mouse adenocarcinomas of the colon) cells. Selected compounds were also assessed for in vivo antimalarial activity in mice infected with $P$. berghei. In addition, the $\mathrm{p} K_{\mathrm{a}}$ values and $\beta$-hematin inhibitory activities of a series of cryptolepine analogues were determined in an attempt to estimate the importance of the accumulation into the parasite food vacuole and the inhibition of $\beta$-hematin formation to the antiplasmodial action of these compounds. Previously, it has been shown that for a series of chloroquine analogues there is a correlation between antiplasmodial activities against a chloroquine-sensitive strain of $P$. falciparum and $\beta$-hematin inhibitory activities, provided account is taken of the accumulation of the compounds into the acidic food vacuole of the parasite. ${ }^{6}$

Chemistry. The 5-bromo (6b), 6-chloro (6c), and $O, N$ diacetylindoxyl derivatives were prepared using a synthesis previously reported for $O, N$-diacetylindoxyl $(\mathbf{6 a})^{9}$ (Scheme 1), although some supplies of $\mathbf{6 b}$ were purchased. The appropriate anthranilic acid derivative $(\mathbf{2 b}$, 2c) was reacted with chloroacetic acid (3) to give phenylglycine-o-carboxylic acid derivatives $(\mathbf{4 b}, \mathbf{4 c})$ that were then $N$-acetylated to give $\mathbf{5 b}$ and $\mathbf{5 c}$. Cyclization of the latter with $\mathrm{Ac}_{2} \mathrm{O}$ in the presence of $\mathrm{Et}_{3} \mathrm{~N}$ gave $O, N$ diacetylindoxyl derivatives $\mathbf{6 b}$ and $\mathbf{6 c}$.

Analogues of 1 were prepared using methodology based on that of Holt and Petrow $(1947)^{10}$ as described previously $^{3}$ (Scheme 2). $O, N$-Acetylindoxyl or a derivative $(\mathbf{6 a}-\mathbf{c})$ was condensed with isatin $(\mathbf{7 a})$ or a derivative $(\mathbf{7 b}-\mathbf{j})$ in the presence of $\mathrm{KOH}$ under anaerobic conditions $\left(\mathrm{N}_{2}\right)$ to give the corresponding quinoline-11carboxylic acid derivatives $(\mathbf{8 a}-\mathbf{o})$. The latter were decarboxylated by heating in diphenyl ether to give quindoline derivatives $(\mathbf{9 a}-\mathbf{o})$ which were subsequently methylated using iodomethane in tetramethylenesulfone to give cryptolepine derivatives $(\mathbf{1 0 a}-\mathbf{o})$ as their
Scheme $1^{a}$
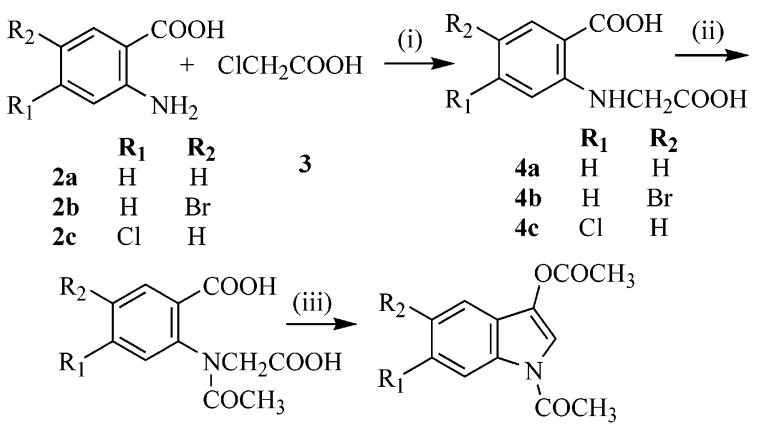

$\begin{array}{llllll} & \mathbf{R}_{\mathbf{1}} & \mathbf{\mathbf { R } _ { 2 }} & & \mathbf{\mathbf { R } _ { 1 }} & \mathbf{\mathbf { R } _ { 2 }} \\ \mathbf{5 a} & \mathrm{H} & \mathrm{H} & \mathbf{6 a} & \mathrm{H} & \mathrm{H} \\ \mathbf{5 b} & \mathrm{H} & \mathrm{Br} & \mathbf{6 b} & \mathrm{H} & \mathrm{Br} \\ \mathbf{5 c} & \mathrm{Cl} & \mathrm{H} & \mathbf{6 c} & \mathrm{Cl} & \mathrm{H}\end{array}$

${ }^{a}$ Reagents and conditions: (i) $\mathrm{Na}_{2} \mathrm{CO}_{3}$; (ii) $\mathrm{Ac}_{2} \mathrm{O}, \mathrm{Na}_{2} \mathrm{CO}_{3}$; (iii) $\mathrm{Ac}_{2} \mathrm{O}, \mathrm{Et}_{3} \mathrm{~N}$, reflux.

hydroiodide salts which were then converted to their hydrochloride salts $(\mathbf{1 1 a}-\mathbf{o})$. Compound 13, 2-bromo7-nitrocryptolepine was prepared from 2-bromocryptolepine (12) (obtained as previously reported ${ }^{3}$ ) by nitration with a mixture of nitric and glacial acetic acids (1:1) (Scheme 3). The substitution of the nitro group at position 7 in 13 was confirmed by NOE difference experiments that showed a connection between the signal for the $5-\mathrm{NCH}_{3}$ and the singlet at $\delta 9.57 \mathrm{ppm}$, (Figure 1), thus eliminating the possibility of 8-nitro substitution. Compounds $\mathbf{1 2}$ and 15-18 (Figure 2) were available from previous work. ${ }^{3}$

\section{Results and Discussion}

In Vitro Antiplasmodial Activity. Table 1 shows the in vitro antiplasmodial and cytotoxic activities of $\mathbf{1}$ and its derivatives together with their cytotoxic/antiplasmodial ratios. Although the limited availability of substituted isatin derivatives restricted the number of cryptolepine analogues that could be made, some interesting structure-activity relationships may be discerned. The 2-chloro analogue (11b) was $\sim 3$-fold more potent than $\mathbf{1}$ against $P$. falciparum while the 2 -fluoro analogue $(\mathbf{1 1 g})$ was $\sim 3$-fold less active than $\mathbf{1}$. From previous work, ${ }^{3}$-bromocryptolepine (12), $\left(\mathrm{IC}_{50}=0.26\right.$ $\mu \mathrm{M})$ was of similar activity to $\mathbf{1 1 b}$. Substitution of a methyl or methoxy group for chlorine in position $2(\mathbf{1 1 h}$, 11i) resulted in a decrease in antiplasmodial activity compared to $\mathbf{1 1 b}$, but 3-methylcryptolepine (11j) was 3 -fold more active than the 3-chloro analogue (11d).

In the case of the monochlorinated analogues, 11b was the most potent, 3-chloro derivative 11d was $\sim 3$ fold less potent, and 4-chlorocryptolepine (11e) was found to be 28-fold less active than 11b. The 8-chloro analogue (11f) was at least 6 -fold less active than $\mathbf{1 1 b}$ ( $1 \mu \mathrm{M}$ was the highest concentration tested). In the case of dichloro substitution, 11a (1,2-dichloro) was 2 -fold more active than $\mathbf{1 1 b}$ (2-chloro) while the activity of 2,3dichlorocryptolepine (11c) was midway between that of $\mathbf{1 1 b}$ and 11d. It would be of interest to prepare 1-chlorocryptolepine to establish whether this is more potent than 11a and 11b, as there appears to be a trend for higher activity from position 4 to position 1 for chloro analogues.

In a previous study ${ }^{3}$ it was shown that 2,7-dibromocryptolepine (15) was 5-fold more active against plasmo- 
Scheme $2^{a}$

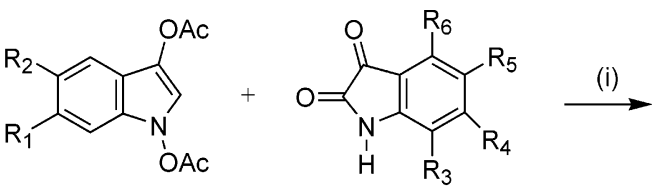

\begin{tabular}{|c|c|c|c|c|c|c|}
\hline $\begin{array}{l}6 a \\
6 b \\
6 c\end{array}$ & $\begin{array}{l}\mathbf{R}_{\mathbf{1}} \\
\mathrm{H} \\
\mathrm{H} \\
\mathrm{Cl}\end{array}$ & $\begin{array}{l}\mathbf{R}_{\mathbf{2}} \\
\mathrm{H} \\
\mathrm{Br} \\
\mathrm{H}\end{array}$ & $\begin{array}{l}7 a \\
7 b \\
7 c \\
7 d \\
7 e \\
7 f \\
7 g \\
7 h \\
7 i \\
7 i\end{array}$ & $\begin{array}{l}\mathbf{R}_{3} \\
\mathrm{H} \\
\mathrm{H} \\
\mathrm{H} \\
\mathrm{H} \\
\mathrm{H} \\
\mathrm{Cl} \\
\mathrm{H} \\
\mathrm{H} \\
\mathrm{H} \\
\mathrm{H}\end{array}$ & $\begin{array}{l}\mathbf{R}_{\mathbf{4}} \\
\mathrm{H} \\
\mathrm{H} \\
\mathrm{H} \\
\mathrm{Cl} \\
\mathrm{Cl} \\
\mathrm{H} \\
\mathrm{H} \\
\mathrm{H} \\
\mathrm{H} \\
\mathrm{CH}_{3}\end{array}$ & $\begin{array}{l}\mathbf{R}_{5} \\
\mathrm{H} \\
\mathrm{Cl} \\
\mathrm{Cl} \\
\mathrm{H} \\
\mathrm{Cl} \\
\mathrm{H} \\
\mathrm{F} \\
\mathrm{CH}_{3} \mathrm{O} \\
\mathrm{CH}_{3} \\
\mathrm{H}\end{array}$ \\
\hline
\end{tabular}<smiles></smiles><smiles>[R]c1cc2[nH]c3cc4c([R6])c([R5])c([R4])c([R])c4c([R])c3c2cc1[R6]</smiles>

10a-o<smiles>[R]c1cc2[nH]c3cc4c([R6])c([R5])c([R4])c([R])c4[n+](C)c3c2cc1[R6]</smiles>

$\mathrm{HCl}$

$\begin{array}{lllllll} & \mathbf{R}_{\mathbf{1}} & \mathbf{R}_{\mathbf{2}} & \mathbf{R}_{\mathbf{3}} & \mathbf{R}_{\mathbf{4}} & \mathbf{R}_{\mathbf{5}} & \mathbf{R}_{\mathbf{6}} \\ \text { 11a } & \mathrm{H} & \mathrm{H} & \mathrm{H} & \mathrm{H} & \mathrm{Cl} & \mathrm{Cl} \\ \text { 11b } & \mathrm{H} & \mathrm{H} & \mathrm{H} & \mathrm{H} & \mathrm{Cl} & \mathrm{H} \\ \text { 11c } & \mathrm{H} & \mathrm{H} & \mathrm{H} & \mathrm{Cl} & \mathrm{Cl} & \mathrm{H} \\ \text { 11d } & \mathrm{H} & \mathrm{H} & \mathrm{H} & \mathrm{Cl} & \mathrm{H} & \mathrm{H} \\ \text { 11e } & \mathrm{H} & \mathrm{H} & \mathrm{Cl} & \mathrm{H} & \mathrm{H} & \mathrm{H} \\ 11 \mathbf{f} & \mathrm{Cl} & \mathrm{H} & \mathrm{H} & \mathrm{H} & \mathrm{H} & \mathrm{H} \\ 11 \mathbf{g} & \mathrm{H} & \mathrm{H} & \mathrm{H} & \mathrm{H} & \mathrm{F} & \mathrm{H} \\ 11 \mathrm{~h} & \mathrm{H} & \mathrm{H} & \mathrm{H} & \mathrm{H} & \mathrm{CH}_{3} & \mathrm{H}\end{array}$

$\begin{array}{lllllll} & \mathbf{R}_{\mathbf{1}} & \mathbf{R}_{\mathbf{2}} & \mathbf{R}_{\mathbf{3}} & \mathbf{R}_{\mathbf{4}} & \mathbf{R}_{\mathbf{5}} & \mathbf{R}_{\mathbf{6}} \\ \mathbf{1 1 \mathbf { i }} & \mathrm{H} & \mathrm{H} & \mathrm{H} & \mathrm{H} & \mathrm{OCH}_{3} \mathrm{H} \\ \mathbf{1 1 j} & \mathrm{H} & \mathrm{H} & \mathrm{H} & \mathrm{CH}_{3} & \mathrm{H} & \mathrm{H} \\ 11 \mathbf{k} & \mathrm{H} & \mathrm{Br} & \mathrm{H} & \mathrm{H} & \mathrm{Cl} & \mathrm{H} \\ 11 \mathbf{1} & \mathrm{H} & \mathrm{Br} & \mathrm{H} & \mathrm{H} & \mathrm{F} & \mathrm{H} \\ 11 \mathbf{m} & \mathrm{H} & \mathrm{Br} & \mathrm{H} & \mathrm{Cl} & \mathrm{H} & \mathrm{H} \\ 11 \mathbf{n} & \mathrm{H} & \mathrm{Br} & \mathrm{H} & \mathrm{CH}_{3} & \mathrm{H} & \mathrm{H} \\ 110 & \mathrm{Cl} & \mathrm{H} & \mathrm{H} & \mathrm{H} & \mathrm{H} & \mathrm{H}\end{array}$

${ }^{a}$ Reagents and conditions: (i) $\mathrm{KOH}, \mathrm{N}_{2}$, reflux; (ii) $\mathrm{Ph}_{2} \mathrm{O}, 250{ }^{\circ} \mathrm{C}$; (iii) $\mathrm{CH}_{3} \mathrm{I}$, tetramethylene sulfone, $50{ }^{\circ} \mathrm{C}$; (iv) $\mathrm{NH}{ }_{4} \mathrm{OH}, \mathrm{HCl}$.

Scheme $3^{a}$

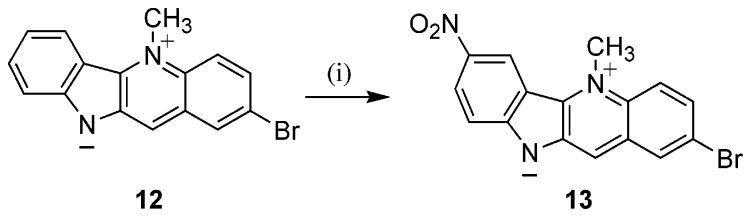

${ }^{a}$ Reagents and conditions: (i) $\mathrm{HNO}_{3}$ : HOAc 1: 1, room temp.

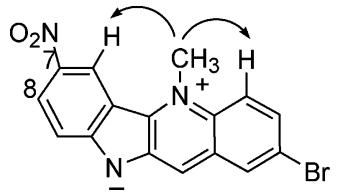

Figure 1. NOE connections from the $\mathrm{N}-\mathrm{CH}_{3}$ in 13.

dia than either the 2-bromo (12), or 7-bromo (14) analogues, and therefore in this study several similar 7-brominated compounds $(\mathbf{1 1 k}-\mathbf{n})$ were prepared. Compounds $11 \mathbf{k}-\mathbf{m}$ showed antiplasmodial activities at least 5-fold greater than their monohalogenated ana-<smiles>[R]c1ccc2c(c1)c([R5])c1[nH]c3c([R4])c([R3])c([R])cc3c1[n+]2C</smiles>

$\begin{array}{llllll} & \mathbf{R}_{\mathbf{1}} & \mathbf{R}_{\mathbf{2}} & \mathbf{R}_{\mathbf{3}} & \mathbf{R}_{\mathbf{4}} & \mathbf{R}_{\mathbf{5}} \\ \mathbf{1 2} & \mathrm{Br} & \mathrm{H} & \mathrm{H} & \mathrm{H} & \mathrm{H} \\ \mathbf{1 4} & \mathrm{H} & \mathrm{Br} & \mathrm{H} & \mathrm{H} & \mathrm{H} \\ \mathbf{1 5} & \mathrm{Br} & \mathrm{Br} & \mathrm{H} & \mathrm{H} & \mathrm{H} \\ \mathbf{1 6} & \mathrm{H} & \mathrm{H} & \mathrm{Cl} & \mathrm{H} & \mathrm{Cl} \\ \mathbf{1 7} & \mathrm{H} & \mathrm{H} & \mathrm{H} & \mathrm{NO}_{2} & \mathrm{H} \\ 18 & \mathrm{H} & \mathrm{NO}_{2} & \mathrm{H} & \mathrm{NO}_{2} & \mathrm{H}\end{array}$

Figure 2. Structures 12 and 14-18.

logues 11b, 11g, and 11d, respectively. However, 7-bromo-3-methylcryptolepine (11n) was only about half as potent as 3-methyl analogue (11j), further supporting the above observation that alkylation appears to be detrimental for antiplasmodial activity. The 2,8-dichlorinated compound $\mathbf{1 1 0}$ was similarly potent as $\mathbf{1 1 k}$ showing that 7-bromo substitution may be replaced with 8-chloro substitution without loss of activity. Similarly, replacement of the 7-bromo substituent with a nitro 
Table 1. In Vitro Antiplasmodial Activities of Cryptolepine Derivatives and Chloroquine Diphosphate and Cytotoxic Activities of Cryptolepine Derivatives Against MAC 15A Cells

\begin{tabular}{|c|c|c|c|}
\hline compound $^{a}$ & activity vs $P$. falciparum in vitro ${ }^{b}$ & activity vs MAC 15 a cells ${ }^{b}$ & cytotoxic/antiplasmodial ratio \\
\hline 1, cryptolepine & $0.440 \pm 0.22$ & $3.95 \pm 1.10$ & 8.98 \\
\hline 11a, 1,2-dichlorocryptolepine & $0.088 \pm 0.005$ & $1.91 \pm 0.35$ & 21.7 \\
\hline 11b, 2-chlorocryptolepine & $0.166 \pm 0.004$ & $2.24 \pm 0.35$ & 13.5 \\
\hline 11c, 2,3 -dichlorocryptolepine & $0.356 \pm 0.008$ & $3.32 \pm 1.24$ & 9.33 \\
\hline 11d, 3-chlorocryptolepine & $0.448 \pm 0.009$ & $1.75 \pm 0.38$ & 3.90 \\
\hline 11e, 4-chlorocryptolepine & $4.69 \pm 0.23$ & $3.54 \pm 0.93$ & 0.76 \\
\hline 11f, 8-chlorocryptolepine & $>1$ & $8.15 \pm 3.44$ & $<8.15$ \\
\hline 11g, 2-fluorocryptolepine & $1.21 \pm 0.05$ & $4.79 \pm 2.21$ & 3.96 \\
\hline 11h, 2-methylcryptolepine & $0.419 \pm 0.016$ & $4.11 \pm 0.82$ & 9.81 \\
\hline 11i, 2-methoxycryptolepine & $0.95^{c}$ & $4.31 \pm 2.48$ & 4.54 \\
\hline 11j, 3-methylcryptolepine & $0.149 \pm 0.012$ & $3.51 \pm 0.55$ & 23.6 \\
\hline 11k, 7-bromo-2-chlorocryptolepine & $0.030 \pm 0.002$ & $1.73 \pm 0.12$ & 57.7 \\
\hline 11l, 7-bromo-2-fluorocryptolepine & $0.063 \pm 0.006$ & $1.35 \pm 0.07$ & 21.4 \\
\hline 11m, 7-bromo-3-chlorocryptolepine & $0.037 \pm 0.005$ & $1.14 \pm 0.19$ & 30.8 \\
\hline 11n, 7-bromo-3-methylcryptolepine & $0.26^{c}$ & $5.21 \pm 0.91$ & 20.0 \\
\hline 11o, 2,8-dichlorocryptolepine & $0.045^{c}$ & $1.12 \pm 0.27$ & 24.9 \\
\hline 13, 2-bromo-7-nitrocryptolepine & $0.07 \pm 0.01$ & $1.03 \pm 0.35$ & 14.7 \\
\hline 15, 2,7-dibromocryptolepine ${ }^{d}$ & $0.049 \pm 0.017$ & $6.04 \pm 0.49$ & 123 \\
\hline chloroquine diphosphate & $0.246 \pm 0.013$ & $\mathrm{NT}^{e}$ & - \\
\hline
\end{tabular}

${ }^{a}$ Tested as hydrochloride salt unless stated otherwise. ${ }^{b} \mathrm{IC}_{50}, \mu \mathrm{M} \pm \mathrm{SD}$; results of three separate determinations. ${ }^{c}$ Mean of two determinations. ${ }^{d}$ Results from ref $3 .{ }^{e} \mathrm{NT}$, not tested.

Table 2. In Vivo Antimalarial Activities of Selected Cryptolepine Derivatives and Chloroquine Diphosphate against $P$. berghei in Mice

\begin{tabular}{|c|c|c|c|c|c|}
\hline compound $^{a}$ & $\begin{array}{l}\text { dose schedule } \\
\left(\mathrm{mg} \mathrm{kg}^{-1} \text { for } 4 \mathrm{~d}\right)\end{array}$ & $\begin{array}{c}\text { mean } \\
\text { parasitemia } \\
(\% \pm \mathrm{SD})\end{array}$ & $\begin{array}{l}\text { suppression of } \\
\text { parasitemia } \\
(\%)\end{array}$ & $\begin{array}{l}\text { mean survival time } \\
\text { of untreated controls, } \\
(\mathrm{d} \pm \mathrm{SD})\end{array}$ & $\begin{array}{l}\text { mean survival time } \\
\text { of treated mice, } \\
(d \pm S D)\end{array}$ \\
\hline 1, cryptolepine $^{b}$ & 20 & $c$ & $c$ & $c$ & $c$ \\
\hline 11g, 2-fluorocryptolepine & 50 & $5.98 \pm 1.91$ & 55.1 & $5.0 \pm 0$ & $5.0 \pm 0$ \\
\hline 11i, 2 -methoxycryptolepine & $50^{d}$ & $12.08 \pm 2.93$ & 9.3 & $5.0 \pm 0$ & $5.0 \pm 0$ \\
\hline 15, 2,7-dibromocryptolepine & 3.125 & $12.10 \pm 1.27$ & 15.9 & $10.0 \pm 0$ & $10.0 \pm 0$ \\
\hline 15 & 6.25 & $7.67 \pm 0.96$ & 46.7 & $10.0 \pm 0$ & $11.6 \pm 0.55$ \\
\hline 15 & 12.5 & $3.55 \pm 0.69$ & 75.4 & $10.0 \pm 0$ & $11.8 \pm 0.45$ \\
\hline 15 & 25.0 & $1.24 \pm 1.01$ & 91.4 & $10.0 \pm 0$ & $15.0 \pm 0$ \\
\hline 11k, 7-bromo-2-chlorocryptolepine & 25.0 & $0.97 \pm 0.98$ & 91.85 & $11.8 \pm 0.45$ & $15.4 \pm 0.89$ \\
\hline 11o, 2,8-dichlorocryptolepine & $25^{e}$ & $9.22 \pm 2.81$ & 17.8 & $9.6 \pm 0.89$ & $14.0 \pm 0$ \\
\hline 13, 2-bromo-7-nitrocryptolepine & $25^{f}$ & $1.34 \pm 0.3$ & 90.75 & $6.4 \pm 1.34$ & $13.0 \pm 0$ \\
\hline chloroquine diphosphate & 10 & 0.00 & 100.0 & 8.56 & $g$ \\
\hline
\end{tabular}

${ }^{a}$ Tested as hydrochloride salt unless otherwise stated. ${ }^{b}$ Results from ref $3 .^{c}$ Toxic after the 2 nd dose. ${ }^{d}$ Last dose not given due to toxicity. ${ }^{e}$ Toxic after two doses; no further doses given. ${ }^{f}$ Mice appeared to suffer pain and/or irritation for a few minutes after injection. $g$ Mice survived test.

group as in $\mathbf{1 3}$ retained antiplasmodial activity similar to that of 2,7-dibromocryptolepine $\left(\mathbf{1 5}, \mathrm{IC}_{50}=0.05 \mu \mathrm{M}\right) .^{3}$

In Vitro Cytotoxicity. For all of the compounds except for 11e, the cytotoxic/antiplasmodial ratios were $>1$ (Table 1), indicating some selectivity against plasmodia even though a long cell-drug exposure time (96 h), was used in the cytotoxicity test. Although the most potent antiplasmodial compounds 11a, 11k-m, 11o, and 13 were all 2 to 4 -fold more cytotoxic than $\mathbf{1}$, their selectivity ratios were all $>10$, the most selective being $\mathbf{1 1 k}$ and $\mathbf{1 1 m}$ (selectivity ratios 57.7 and 30.8, respectively). However, in vitro cytotoxicity did not parallel toxicity in vivo, as $\mathbf{1 1 k}$ and $\mathbf{1 3}$ were not toxic to mice despite having greater in vitro cytotoxicity than $\mathbf{1}$, whereas $\mathbf{1 1 i}$ that had similar cytototoxicity to $\mathbf{1}$ did exhibit toxicity in mice.

In Vivo Antimalarial Activity. Selected compounds were assessed for antimalarial activity against $P$. berghei in mice using Peters's 4-day suppressive test in which activity is determined by comparing parasitemias of animals treated for 4 days with those of untreated controls on day $5 .{ }^{11}$ Observation of the mice was then continued in order to record their survival times (taken as the number of days before illness due to malaria became apparent). In previous work ${ }^{3}$ it was shown that $\mathbf{1}$ is toxic to mice after 2 doses of $20 \mathrm{mg} \mathrm{kg}^{-1}$, but some analogues, notably 2,7-dibromocryptolepine (15), was not toxic at a dose of $12.5 \mathrm{mg} \mathrm{kg}^{-1}$ for 4 days and suppressed parasitemia by $89 \%$. Here we report further experiments in which four dose levels of $\mathbf{1 5}$ were used to examine the dose-response relationship. As shown in Table 2, a clear dose-dependent response was seen with doses ranging from 3.125 to $25 \mathrm{mg} \mathrm{kg}^{-1} \mathrm{day}^{-1}$, and the $\mathrm{ED}_{50}$ and $\mathrm{ED}_{90}$ values were 6.92 and $21.46 \mathrm{mg} \mathrm{kg}^{-1}$ day $^{-1}$, respectively. At the highest dose $\left(25 \mathrm{mg} \mathrm{kg}^{-1}\right.$ day $^{-1}$ ) parasitemia was suppressed by $91.4 \%$, there was no apparent toxicity, and the mice survived 5 days longer than the untreated controls. Similar results in terms of both suppression of parasitemia and survival were obtained with $\mathbf{1 1 k}$ and with 13 with no apparent toxicity to the mice, but the 2,8-dichloro analogue 110 showed signs of toxicity after the second dose, so that no further doses were administered. Compounds $\mathbf{1 1}$ g and $\mathbf{1 1 i}$ were less active against $P$. berghei in vivo, which was consistent with their relatively weak antiplasmodial activities in vitro.

Correlation of Antiplasmodial Activities with Ability To Inhibit $\beta$-Hematin Formation. To predict the accumulation of cryptolepine derivatives into the acidic parasite food vacuole, $\mathrm{p} K_{\mathrm{a}}$ values for a number 
Table 3. Relationship between $\mathrm{p} K_{\mathrm{a}}$, Normalized Antiplasmodial $\mathrm{IC}_{50}$ Values, and Inhibition of $\beta$-Hematin Formation for 1, Some Analogues of $\mathbf{1}$, and Chloroquine Diphosphate

\begin{tabular}{lcccccc}
\hline \multicolumn{1}{c}{ compound $^{a}$} & $\mathrm{IC}_{50^{b}}$ & $\mathrm{p} K_{\mathrm{a}}{ }^{c}$ & acc. ratio $^{d}$ & $\alpha^{e}$ & IC $_{50} \times \alpha^{f}$ & BHIA $_{50^{g}}$ \\
\hline 1, cryptolepine sulfate & $0.44 \pm 0.22$ & 11.8 & 79.43 & 1.00 & 0.44 & $1.64 \pm 0.007$ \\
11i, 2-methoxycryptolepine & 0.95 & 1.45 & 79.42 & 1.00 & 0.95 & $1.96 \pm 0.89$ \\
$\mathbf{1 1 g}$, 2-fluorocryptolepine & $1.21 \pm 0.05$ & 11.25 & 79.41 & 1.00 & 1.21 & $1.24 \pm 0.43$ \\
12, 2-bromocryptolepine & $0.26 \pm 0.09$ & 10.2 & 79.30 & 1.00 & 0.26 & $0.63 \pm 0.10$ \\
17, 9-nitrocryptolepine & $6.92 \pm 1.89$ & 9.60 & 78.94 & 0.99 & 6.85 & $0.84 \pm 0.001$ \\
$\mathbf{1 5}$, 2,7-dibromocryptolepine & $0.049 \pm 0.017$ & 9.10 & 77.90 & 0.99 & 0.049 & $1.53 \pm 0.28$ \\
$\mathbf{1 6}, 8,11$-dichlorocryptolepine & $27.0 \pm 5.4$ & 7.35 & 37.94 & 0.48 & 12.91 & $0.96^{h}$ \\
18, 7,9-dinitrocryptolepine & $0.65 \pm 0.21$ & 6.40 & 0.813 & 0.01 & 0.0065 & $0.92 \pm 0.19$ \\
chloroquine diphosphate & $0.18 \pm 0.02$ & $8.55,9.81^{i}$ & $5896^{j}$ & $74.2^{j}$ & $13.36^{j}$ & $1.44 \pm 0.16$ \\
\hline
\end{tabular}

${ }^{a}$ Tested as hydrochloride salts except where otherwise stated. ${ }^{b}$ From ref 3 ; antiplasmodial activity against $P$. falciparum (K1), IC 50 , $\mu \mathrm{M} \pm \mathrm{SD}$; mean of not less than three separate determinations except for 11i which is the mean of two determinations. ${ }^{c}$ Mean of two determinations; all duplicates were within \pm 0.1 of the mean value. ${ }^{d}$ Vacuolar accumulation ratio calculated using eq 1 and assuming a vacuolar $\mathrm{pH}$ of 5.5 and external $\mathrm{pH}$ of $7.4 .^{8}{ }^{e}$ Accumulation ratio relative to cryptolepine. $f$ Normalized $\mathrm{IC}_{50} .{ }^{g} \beta$-Hematin inhibitory activity in equivalents of drug relative to hematin causing $50 \%$ inhibition; mean of two determinations \pm SD. ${ }^{h}$ Incompletely soluble; result of one determination. ${ }^{i}$ Data from ref $8 .{ }^{j}$ Predicted values may not apply as a chloroquine resistant strain of $P$. falciparum was used.

of derivatives were measured, and these were found to range from 11.8 for $\mathbf{1}$ down to 6.4 for $\mathbf{1 8}$ (Table 3). For all of the compounds examined, the UV spectra recorded in buffers at different $\mathrm{pH}$ values showed only one isosbestic point, indicating that only one protonable nitrogen atom is present, and these data are consistent with the ${ }^{1} \mathrm{H}$ NMR spectra of $\mathbf{1}$ and its derivatives in which the signals for the 5- $N$ methyl groups have a chemical shift $(\delta)$ of $\sim 5 \mathrm{ppm}$ typical of quaternary $N$-methyl groups so that $N$-10 is the only basic nitrogen. ${ }^{3}$ The extent of $\mathrm{pH}$ trapping of each of the compounds into the acidic parasite food vacuole was calculated from their $\mathrm{p} K_{\mathrm{a}}$ values using eq 1 below $^{6}$ except that the right-hand top and bottom terms were omitted, as these are applicable only for compounds such as chloroquine that have two protonable nitrogen atoms.

$$
\frac{[Q]_{v}}{[Q]_{e}}=\frac{\left\{1+\frac{\left[\mathrm{H}^{+}\right]_{v}}{\mathrm{~K}_{a 2}}+\frac{\left[\mathrm{H}^{+}\right]_{v}^{2}}{K_{a 1} K_{a 2}}\right\}}{\left\{1+\frac{\left[\mathrm{H}^{+}\right]_{e}}{K_{a 2}}+\frac{\left[\mathrm{H}^{+}\right]_{e}^{2}}{K_{a 1} K_{a 2}}\right\}}
$$

In eq $1,[Q]_{\mathrm{v}}$ and $[Q]_{\mathrm{e}}$ represent the vacuolar and external drug concentrations and $\left[\mathrm{H}^{+}\right]_{\mathrm{v}}$ and $\left[\mathrm{H}^{+}\right]_{\mathrm{e}}$ represent the vacuolar and external hydrogen ion concentrations, respectively. The vacuolar and the external $\mathrm{pH}$ values were taken to be 5.5 and 7.4 , respectively. ${ }^{6}$ The calculated accumulation ratios are shown in Table 3 , and the accumulation ratios relative to $\mathbf{1}(\alpha)$ are also given. By multiplying the values for $\alpha$ with the experimentally obtained antiplasmodial $\mathrm{IC}_{50}$ values for each compound, the normalized $\mathrm{IC}_{50}$ values $\left(\mathrm{IC}_{50} \times \alpha\right)$ are obtained; i.e., the $\mathrm{IC}_{50}$ values theoretically expected if the compounds accumulated in the vacuole to the same extent as cryptolepine. Having adjusted for the differential accumulation of the compounds, comparison of the normalized antiplasmodial $\mathrm{IC}_{50}$ values with the $\mathrm{IC}_{50}$ values for the inhibition of $\beta$-hematin formation should indicate whether a clear correlation exists between their antiplasmodial activities and their abilities to inhibit $\beta$-hematin formation.

As shown in Table 3, the concentration of $\mathbf{1}$ in the acidic food vacuole of the parasite is predicted to be 79.4fold higher than that in the extracellular fluid. Compounds with $\mathrm{p} K_{\mathrm{a}}$ values of 9.1 or above $(\mathbf{1 1 i}, \mathbf{1 1} \mathrm{g}, \mathbf{1 2}$, $\mathbf{1 5}, \mathbf{1 7})$, are expected to achieve similar vacuolar con-

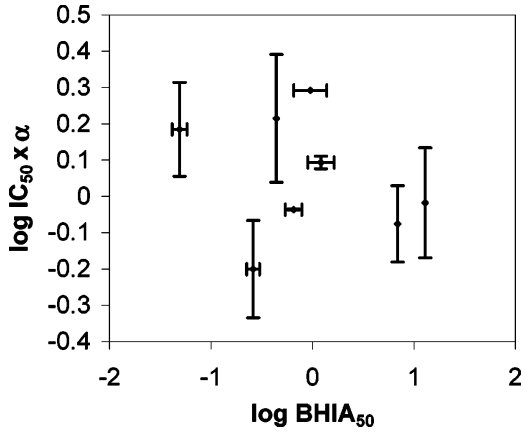

Figure 3. Plot of the log of the normalized antiplasmodial $\mathrm{IC}_{50}\left(\mathrm{IC}_{50} \times \alpha\right)$ versus the log of the activity against the inhibition of $\beta$-haematin formation for $\mathbf{1}$, and some analogues of 1 (Table 3). No correlation is seen; $r^{2}=0.0781$. Error bars represent $1 \mathrm{SEM}$; in the calculation of errors for $\mathrm{IC}_{50} \times \alpha, \mathrm{p} K_{\mathrm{a}}$ errors have been ignored, as these are very small compared to those for the antiplasmodial values.

centrations to $\mathbf{1}$, and hence their normalized $\mathrm{IC}_{50}$ values $\left(\mathrm{IC}_{50} \times \alpha\right)$ are almost identical to their experimental antiplasmodial $\mathrm{IC}_{50}$ values. In contrast, the predicted accumulations $(\alpha)$ of $\mathbf{1 6}$ and $\mathbf{1 8}$ relative to $\mathbf{1}$ are 0.48 and 0.01 , respectively, so that their normalized $\mathrm{IC}_{50}$ values are smaller than the corresponding experimental values. The quantities of the compounds required to inhibit the formation of $\beta$-hematin by $50 \%$ (BHIA $_{50}$ values) ranged from 0.63 to 1.96 equiv of drug relative to hematin, the value for $\mathbf{1}$ (1.64) being close to that for chloroquine diphosphate (1.44). A plot of $\log \mathrm{IC}_{50} \times \alpha$ against $\log$ BHIA $_{50}$ values (Figure 3 ) shows that there is no correlation at all between the normalized $\mathrm{IC}_{50}$ values and the ability of compounds to inhibit $\beta$-hematin formation $\left(r^{2}=0.0781\right)$. Kaschula et al. ${ }^{6}$ reported that a direct proportionality between antiplasmodial activity normalized for $\mathrm{pH}$ trapping and $\beta$-hematin inhibitory activity was observed with a series of 4-aminoquinolines using a chloroquine-sensitive strain of $P$. falciparum (D10). In this study a chloroquine-resistant strain of $P$. falciparum (K1) was used, but it has been shown previously that there was no cross-resistance between a series of analogues of $\mathbf{1}$ and chloroquine ${ }^{3}$ so that resistance mechanisms such as enhanced efflux of drug from the parasite food vacuole that may occur in chloroquine-resistant parasites ${ }^{12}$ are unlikely to have affected the vacuolar accumulation of the compounds investigated in this study. 
The most potent antiplasmodial compound, $\mathbf{1 5}$, is 9-fold more active than $\mathbf{1}$ against plasmodia, but its relative accumulation and its effect on $\beta$-hematin formation are nearly identical to that of $\mathbf{1}$, suggesting that the increased antiplasmodial potency of this analogue is due neither to better accumulation nor to enhanced activity against $\beta$-hematin formation. Conversely, the accumulation of $\mathbf{1 8}$ into the parasite food vacuole is only about $1 \%$ of that of 1 so that a very low normalized IC $_{50}$ value $(0.0065 \mu \mathrm{M})$ results, but the activity of $\mathbf{1 8}$ on $\beta$-hematin formation is only $50 \%$ greater than that of 1. These results suggest that the antiplasmodial mode of action of $\mathbf{1}$ and its analogues is only partially due to the inhibition of hemozoin formation. In the case of $\mathbf{1}$, it is likely that the latter action is complemented by effects resulting from the intercalation of $\mathbf{1}$ into DNA and possibly effects on parasite topoisomerase II, as similar effects appear to be related to the toxicity of $\mathbf{1}$ to mammalian cells ${ }^{5}$ and in one study using fluorescence microscopy it was reported that $\mathbf{1}$ was localized in the parasite to a structure that may correspond to the nucleus. ${ }^{13}$ However, this may not be the case with $\mathbf{1 2}$, $\mathbf{1 5}, \mathbf{1 7}$, and 18, as these analogues were shown to have less ability to intercalate into DNA than $\mathbf{1}$ as judged from their effects on the melting point ( $\Delta T_{\mathrm{m}}$ values) of DNA. ${ }^{3}$ Nevertheless, surprisingly the latter analogues were not less cytotoxic than $\mathbf{1}$ against mouse adenocarcinoma (MAC15A) cells, although in contrast to $\mathbf{1}$ they were not toxic to mice when assessed for antimalarial activity in vivo. ${ }^{3}$ Analogue $\mathbf{1 5}$ is markedly more potent than 1 against malaria parasites in vitro and has encouraging in vivo activity in mice infected with $P$. berghei (Table 2) which suggests that a selective antiplasmodial mechanism in addition to the inhibition of hemozoin formation is operating. Further work to investigate this would be worthwhile and may lead to the design of more effective antimalarial analogues of 1.

While the inhibitory activities of analogues of $\mathbf{1}$ and of chloroquine against the formation of $\beta$-hematin are of the same order, the accumulation ratio of chloroquine into the parasite food vacuole as predicted by eq 1 (taking the $\mathrm{p} K_{\mathrm{a}}$ values to be 8.55 and $9.81^{6}$ ) is 5896 , more than 70-fold greater than that for 1 (79.4) although the accumulation of chloroquine in chloroquine-resistant parasites may be compromised by increased efflux. ${ }^{12}$ This large difference in accumulation between $\mathbf{1}$ and chloroquine results because $\mathbf{1}$ has only one basic (protonable) nitrogen whereas chloroquine has two. It is possible that the association of $\mathbf{1}$ with hemin would in itself lead to an accumulation of drug into the parasite food vacuole independently of a $\mathrm{pH}$ trapping mechanism, but studies with chloroquine have shown that at concentrations in the region of the $\mathrm{IC}_{50}$ of chloroquine, negligible association with hemin would occur in the absence of $\mathrm{pH}$ trapping because the affinity of chloroquine for hematin is too weak. ${ }^{6}$ For aminoquinolines, affinity for hematin correlates with their abilities to inhibit $\beta$-hematin formation, and as the latter activities for $\mathbf{1}$ and its analogues are comparable to that of chloroquine (Table 3), it is unlikely that $\mathbf{1}$ and its derivatives will have sufficient affinity for heme to drive their accumulation in the food vacuole in the absence of another mechanism. If $\mathrm{pH}$ trapping is important for the antiplasmodial action of $\mathbf{1}$ and its analogues, then the addition of another protonable nitrogen to the molecule may be expected to lead to an increase in potency. The synthesis of such analogues, for example related to $\mathbf{1 5}$, is currently in progress.

\section{Conclusion}

Six of the 16 analogues of $\mathbf{1}(\mathbf{1 1 a}, \mathbf{1 1 k}, \mathbf{1 1 l}, \mathbf{1 1 m}, \mathbf{1 1 o}$ 13), were found to have potent in vitro antiplasmodial activities with $\mathrm{IC}_{50}$ values $<0.1 \mu \mathrm{M}$. The presence of a halogen or nitro group in position 7 in addition to a halogen substituent in the quinoline ring were found to be beneficial for activity while alkyl or alkoxy substitution in the ring was detrimental. A comparison of chlorinated analogues showed that the position of substitution in the quinoline ring substantially affected antiplasmodial activity, with substitution in positions 1 and 2 being most favorable, but their cytototoxic activities did not follow this trend.

Two novel compounds, 11k and $\mathbf{1 3}$ were shown to have encouraging antimalarial activities in vivo with suppression of parasitemias $>90 \%$ and increased survival of animals without any apparent toxicity to the mice even though they were more cytotoxic than $\mathbf{1}$ in vitro. Compound 15, available from previous work ${ }^{3}$ was found to produce a dose-dependent decrease in parasitaemia and increased survival compared to untreated malaria-infected mice.

Experiments designed to explore the mode of action of $\mathbf{1}$ indicated that there is no correlation between the inhibition of $\beta$-hematin formation and the antiplasmodial activity of analogues of $\mathbf{1}$ even when account is taken of the predicted accumulation of the compounds into the acidic food vacuole of the parasite by $\mathrm{pH}$ trapping. The data suggests that especially for $\mathbf{1 5}$ there is likely to be another mechanism(s) operating in addition to the inhibition of hemozoin formation that may account for the potent and selective antiplasmodial activity of this compound.

This study supports the continued synthesis and investigation of derivatives of $\mathbf{1}$ in the search for new antimalarial agents.

\section{Experimental Section}

Chemistry. Isatin derivatives $\mathbf{7 b}-\mathbf{j}$ were made available to us (see acknowledgments), but some notes on their synthesis are given below for completeness. All other chemicals were purchased from Sigma-Aldrich Chemical Co. Ltd., Poole, U.K. ${ }^{1} \mathrm{H}$ NMR spectra were acquired on a JEOL GX270 FT NMR spectrometer at $270 \mathrm{MHz}$. NOE experiments on 13 were carried out in DMSO- $d_{6}$ at $25^{\circ} \mathrm{C}$ on a JEOL ECA $600 \mathrm{NMR}$ spectrometer at $600 \mathrm{MHz}$. Mass spectra were run on an AEI MS902 spectrometer equipped with an MSS data acquisition system, version 10 (Mass Spectrometer Services, Manchester, U.K.). C, H, and $\mathrm{N}$ analyses were carried out by the Chemical and Materials Analysis Unit, University of Newcastle, U.K. on a Carlo Erba 1106 elemental analyzer.

Note on the Synthesis of the Isatin Derivatives Used in This Study. Compounds $\mathbf{7 b}-\mathbf{j}$ were prepared by the Sandmeyer method ${ }^{14,15}$ by condensation of a substituted aniline with chloral hydrate and hydroxylamine to form the corresponding isonitrosoacetanilide using about $50 \mathrm{~g}$ amounts of the aniline. Other published synthetic routes proved to be unsatisfactory. This reaction is not without hazard, since significant amounts of HCN are generated as a gaseous byproduct, partly or entirely by decomposition of the formed isonitrosoacetanilide. ${ }^{16,17}$ The solid isonitrosoacetanilide was 
then heated with $\mathrm{H}_{2} \mathrm{SO}_{4}$, heating to temperatures no higher than $70{ }^{\circ} \mathrm{C}$. When this method was originally developed, $\mathrm{H}_{2}$ $\mathrm{SO}_{4}$ then available was probably less concentrated that the $98 \%$ used now; the use of concentrated $\mathrm{H}_{2} \mathrm{SO}_{4}$ often leads to the formation of byproducts including a black resin that is difficult to filter. The most satisfactory results were obtained with acid corresponding to the monohydrate; at lower concentrations ring closure to form isatins was poor. When the reaction proceeded so as to give a good yield, the solution usually became violet. The reaction mixture was quenched by pouring onto ice when the crude isatin usually precipitated. The isatin was purified by dissolving in aqueous $\mathrm{NaOH}$ and adjusting the $\mathrm{pH}$ to neutrality when dark, resinous byproducts usually separated. On acidification, the released substituted isatinic acid eliminated a molecule of water on ring closure to form the isatin, sometimes slowly.

Ortho-, meta-, and para-substituted anilines formed 7-, a mixture of 4- and 6-, and 5-substituted isatins, respectively. Mixtures of 4- and 6-substituted derivatives were separated ${ }^{18}$ by acidification of the sodium isatinate solution with acetic acid, when the 4-substituted isatin was released (usually as red needles). The mother liquors were acidified with $\mathrm{HCl}$, when the 6-substituted isatin was released, usually as yellow plates. The reaction between some isatin precursors and $\mathrm{H}_{2} \mathrm{SO}_{4}$ resulted in a red solution instead of violet, and no isatin was deposited on quenching with ice. Ether extraction of the quenched reaction mixture extracted a small amount of material, and by repeated extraction with ether and backextraction into a small volume of aqueous $\mathrm{NaOH}$, a small amount of the expected isatin was obtained on acidification. The red ether-insoluble byproduct may have been an isatin sulfonic acid.

General Method for Preparation of Halogenated Cryptolepine Derivatives (11a-o). $O, N$-Acetylindoxyl $(6 \mathbf{6})(5 \mathrm{~g}$, $23 \mathrm{mmol}$ ) for $\mathbf{1 1 a}-\mathbf{e}$ and $\mathbf{1 1} \mathbf{g}-\mathbf{j}, 5$-bromo- $O, N$-acetylindoxyl (6b) $(6.84 \mathrm{~g}, 23 \mathrm{mmol})$ for $\mathbf{1 1 k}-\mathbf{n}$, or 6 -chloro- $O, N$-acetylindoxyl (6c) $(6.11 \mathrm{~g}, 23 \mathrm{mmol})$ for $11 \mathrm{f}$ and $11 \mathrm{o}$ and water (50 $\mathrm{mL}$ ) were stirred under nitrogen at room temperature. A solution of isatin ( $\mathbf{7 a}$ ) or a derivative $\mathbf{7 b}-\mathbf{j}(23 \mathrm{mmol})$ and $\mathrm{KOH}$ $(26 \mathrm{~g}, 0.46 \mathrm{M})$ in water $(50 \mathrm{~mL})$ was slowly added. The reaction mixture was refluxed for $4 \mathrm{~h}$ and then cooled to $70{ }^{\circ} \mathrm{C}$; air was then bubbled through the liquid for $20 \mathrm{~min}$. The mixture was filtered, and the filtrate was acidified to $\mathrm{pH} 1$ with concentrated $\mathrm{HCl}$. The precipitate of quindoline-11-carboxylic acid derivative $\mathbf{8} \mathbf{a}-\mathbf{o}$ was collected, washed with water, dried, and used for the next step without further purification. Decarboxylation was carried out by refluxing the latter product with diphenyl ether $(50 \mathrm{~mL})$ for $6 \mathrm{~h}$. After the mixture was cooled, it was poured into petroleum ether $(200 \mathrm{~mL})$ and allowed to stand overnight at $4{ }^{\circ} \mathrm{C}$. The precipitate was collected, washed with petroleum ether, and dried. The product, a quindoline derivative $\mathbf{9 a}-\mathbf{o}$, was then dissolved in the minimum amount of tetramethylenesulfone $(5-10 \mathrm{~mL})$, and an excess of iodomethane $(2-3 \mathrm{~mL})$ was added. The reaction vessel was sealed and heated with stirring at $60^{\circ} \mathrm{C}$ overnight. When cool, the reaction mixture was poured into ether $(200 \mathrm{~mL})$, and the reaction vessel was washed with a little methanol; this was then added to the ether that was allowed to stand overnight at $4{ }^{\circ} \mathrm{C}$. The precipitate of the cryptolepine derivative as the hydroiodide salt 10a-o was collected and washed with ether and then dissolved in a mixture of chloroform:methanol: $\mathrm{NH}_{4}$ $\mathrm{OH}(35 \%), 90: 10: 1$. The solution was filtered, washed with water, dried over anhydrous $\mathrm{Na}_{2} \mathrm{SO}_{4}$, filtered again, and evaporated to dryness under reduced pressure $\left(40^{\circ} \mathrm{C}\right)$. Purification was carried out by column-chromatographing the product over silica gel $\mathrm{G}$ ( $60 \mu \mathrm{M}$, TLC grade), under positive pressure eluting with chloroform containing increasing amounts of methanol. Cryptolepine derivatives $\mathbf{1 0 a}-\mathbf{o}$ were converted to their hydrochloride salts $\mathbf{1 1 a}-\mathbf{o}$ by adding $\mathrm{HCl}$ in methanol $(5 \%)$ and then crystallizing from chloroform/methanol or chloroform/methanol/ethyl acetate.

1,2-Dichlorocryptolepine Hydrochloride (11a). The title compound was prepared as above from $\mathbf{6 a}(23 \mathrm{mmol}, 5.0$ g) and $\mathbf{7 b}(23 \mathrm{mmol}, 3.38 \mathrm{~g})$. Yellow crystals, yield $10.9 \% .{ }^{1} \mathrm{H}$
NMR of free base $\left(\mathrm{CDCl}_{3} \delta\right): 4.70\left(3 \mathrm{H}, \mathrm{s}, \mathrm{NCH}_{3}\right), 7.02(1 \mathrm{H}, \mathrm{t}$, $J=7.4 \mathrm{~Hz}, 7$ or $8-H), 7.54(1 \mathrm{H}, \mathrm{t}, J=6.7 \mathrm{~Hz}, 7$ or $8-H), 7.78$ $(1 \mathrm{H}, \mathrm{d}, J=8.4 \mathrm{~Hz}, 6-H), 8.10(1 \mathrm{H}, \mathrm{d}, J=8.4 \mathrm{H}, 9-H), 8.21$ $(2 \mathrm{H}, \mathrm{m}, 3-\mathrm{H}, 4-\mathrm{H}), 8.61(1 \mathrm{H}, \mathrm{s}, 11-\mathrm{H})$. MS (EI, $\mathrm{m} / z$, relative intensity, \%) $301(25)\left[\mathrm{M}^{+}\right], 286$ (71), 266 (52), 252 (100), 217 (25), 190 (12), 142 (52). Anal. $\left(\mathrm{C}_{16} \mathrm{H}_{10} \mathrm{~N}_{2} \mathrm{Cl}_{2} \cdot 1.5 \mathrm{HCl}\right) \mathrm{C}, \mathrm{H}, \mathrm{N}$.

2,3-Dichlorocryptolepine Hydrochloride (11c). The title compound was prepared as above from $\mathbf{6 a}(23 \mathrm{mmol}, 5.0$ g) and 7c (23 mmol, $4.95 \mathrm{~g})$. Yellow crystals, yield $1.1 \% .{ }^{1} \mathrm{H}$ NMR of free base $\left(\mathrm{CDCl}_{3} \delta\right): 4.80\left(3 \mathrm{H}, \mathrm{s}, \mathrm{NCH}_{3}\right), 7.05(1 \mathrm{H}, \mathrm{t}$, $J=7.4 \mathrm{~Hz}, 7$ or $8-H), 7.55(1 \mathrm{H}, \mathrm{t}, J=7.2 \mathrm{~Hz}, 7$ or $8-H), 7.56-$ $8.11(3 \mathrm{H}, \mathrm{m}, 3 \mathrm{Ar}-H), 8.63(1 \mathrm{H}, \mathrm{s}, 1$ or $4-H), 9.14(1 \mathrm{H}, \mathrm{s}, 11-H)$. MS (EI, $m / z$, relative intensity, \%) $301(18)\left[\mathrm{M}^{+}\right], 288(66), 286$ (100), 252 (58), 216 (16), 188 (7), 142 (28). Anal. $\left(\mathrm{C}_{16} \mathrm{H}_{10} \mathrm{~N}_{2^{-}}\right.$ $\left.\mathrm{Cl}_{2} \cdot \mathrm{HCl}\right) \mathrm{C}, \mathrm{H}, \mathrm{N}$.

3-Chlorocryptolepine Hydrochloride (11d). The title compound was prepared as above from 6 a $(23 \mathrm{mmol}, 5.0 \mathrm{~g})$ and $7 \mathbf{d}$ (23 mmol, $4.18 \mathrm{~g})$. Yellow crystals, yield $8.51 \% .{ }^{1} \mathrm{H}$ NMR of free base $\left(\mathrm{CDCl}_{3}, \delta\right): 4.70\left(3 \mathrm{H}, \mathrm{s}, \mathrm{NCH}_{3}\right), 6.97(1 \mathrm{H}, \mathrm{t}$, $J=7.4 \mathrm{~Hz}, 7$ or $8-H), 7.51(1 \mathrm{H}, \mathrm{t}, J=6.9 \mathrm{~Hz}, 7$ or $8-H), 7.54$ $(1 \mathrm{H}, \mathrm{d}, J=8.7 \mathrm{~Hz}, 6-H), 7.80(1 \mathrm{H}, \mathrm{d}, J=8.7 \mathrm{~Hz}, 9-H), 8.03$ $(1 \mathrm{H}, \mathrm{s}, 4-H), 8.07(1 \mathrm{H}, \mathrm{d}, J=2.97 \mathrm{~Hz}, 1-H), 8.10(1 \mathrm{H}, \mathrm{d}, J=$ $3.5 \mathrm{~Hz}, 2-H), 8.70(1 \mathrm{H}, \mathrm{s}, 11-H)$. MS (EI, $\mathrm{m} / z$, relative intensity, \%) 267 (100) $\left[\mathrm{M}^{+}\right], 251$ (35), 231 (8), 222 (8), 216 (12), 190 (4). Anal. $\left(\mathrm{C}_{16} \mathrm{H}_{11} \mathrm{~N}_{2} \mathrm{Cl} \cdot \mathrm{HCl}\right) \mathrm{C}, \mathrm{H}, \mathrm{N}$.

4-Chlorocryptolepine Hydrochloride (11e). The title compound was prepared as above from $6 \mathbf{a}(23 \mathrm{mmol}, 5.0 \mathrm{~g})$ and $7 \mathbf{f}(23 \mathrm{mmol}, 4.18 \mathrm{~g})$. Yellow crystals, yield $4.1 \% .{ }^{1} \mathrm{H} \mathrm{NMR}$ of free base $\left(\mathrm{CDCl}_{3}, \delta\right): 4.80\left(3 \mathrm{H}, \mathrm{s}, \mathrm{NCH}_{3}\right), 7.05(1 \mathrm{H}, \mathrm{t}, J=$ $7.4 \mathrm{~Hz}, 7$ or $8-H), 7.45(1 \mathrm{H}, \mathrm{dd}, 1-H), 7.55(1 \mathrm{H}, \mathrm{t}, J=6.9 \mathrm{~Hz}$, 7 or $8-H), 7.85(2 \mathrm{H}, \mathrm{m}, 6-H, 9-H), 8.15(2 \mathrm{H}, \mathrm{m}, 2-H, 3-H), 8.80$ $(1 \mathrm{H}, \mathrm{s}, 11-\mathrm{H})$. MS (EI, $\mathrm{m} / z$, relative intensity, \%) $266(84)\left[\mathrm{M}^{+}\right]$, 252 (100), 232 (15), 216 (13), 190 (6), 126 (12), 108 (5). Anal. $\left(\mathrm{C}_{16} \mathrm{H}_{11} \mathrm{~N}_{2} \mathrm{Cl} \cdot 1.5 \mathrm{HCl} \cdot 2 \mathrm{H}_{2} \mathrm{O}\right) \mathrm{C}, \mathrm{H}, \mathrm{N}$.

8-Chlorocryptolepine Hydrochloride (11f). The title compound was prepared as above from $6 \mathbf{c}(23 \mathrm{mmol}, 6.11 \mathrm{~g})$ and $\mathbf{7 a}(23 \mathrm{mmol}, 3.38 \mathrm{~g})$. Yellow crystals, yield $15 \% .{ }^{1} \mathrm{H}$ NMR of free base $\left(\mathrm{CDCl}_{3}, \delta\right): 4.80\left(3 \mathrm{H}, \mathrm{s}, \mathrm{NCH}_{3}\right), 7.01(1 \mathrm{H}, \mathrm{dd}, J=$ $2.0,9.2, \mathrm{~Hz}, 1-H$ or $4-H), 7.60(1 \mathrm{H}, \mathrm{t}, J=7.9,2-H$ or $3-H), 7.8$ $(1 \mathrm{H}, \mathrm{d}, J=1.7 \mathrm{~Hz}, 9-H), 7.9(1 \mathrm{H} \mathrm{dt}, J=1.6,6.7 \mathrm{~Hz}, 2-H$ or $3-H), 8.11(1 \mathrm{H}, \mathrm{d}, J=8.9,1-H$ or $4-H), 8.13(1 \mathrm{H}, \mathrm{d}, J=8.7$, $6-H), 8.19(1 \mathrm{H}, \mathrm{dd} J=1.7,8.4,7-H), 8.83(1 \mathrm{H}, \mathrm{s}, 11-H)$. MS (EI, $m / z$, relative intensity, \%) $267(33)\left[\mathrm{M}^{+}\right], 266(100)\left[\mathrm{M}^{+}\right]$, 251 (22), 250 (26), 216 (6), 133, (5). Anal. $\left(\mathrm{C}_{16} \mathrm{H}_{11} \mathrm{~N}_{2} \mathrm{Cl} \cdot 1.5 \mathrm{HCl}\right)$ C, H, N

7-Bromo-2-chlorocryptolepine Hydrochloride (11k). The title compound was prepared as above from $\mathbf{6 b}(23 \mathrm{mmol}$, $6.84 \mathrm{~g})$ and $\mathbf{7 b}(23 \mathrm{mmol}, 4.18 \mathrm{~g})$. Yellow crystals, yield $13.0 \%$. ${ }^{1} \mathrm{H}$ NMR of free base $\left(\mathrm{CDCl}_{3}, \delta\right): 4.70\left(3 \mathrm{H}, \mathrm{s}, \mathrm{NCH}_{3}\right), 7.45(1 \mathrm{H}$, $\mathrm{d}, J=9.2 \mathrm{~Hz}, 9-H), 7.54(1 \mathrm{H}, \mathrm{d}, J=8.9 \mathrm{~Hz}, 8-H), 7.72(1 \mathrm{H}, \mathrm{d}$, $J=9.4,4-H), 8.00(1 \mathrm{H}, \mathrm{d}, J=9.4 \mathrm{~Hz}, 3-H), 8.04(1 \mathrm{H}, \mathrm{s}, 1-\mathrm{H}$ or $6-H), 8.09(1 \mathrm{H}, \mathrm{s}, 1-H$ or $6-H), 8.50(1 \mathrm{H}, \mathrm{s}, 11-H)$. MS (EI, $\mathrm{m} / z$, relative intensity, \%) $346(100)\left[\mathrm{M}^{+}\right], 344(64)\left[\mathrm{M}^{+}\right], 332$ (80), 330 (62), 251 (18), 215 (15), 142 (15), 108 (10). Anal. $\left(\mathrm{C}_{16} \mathrm{H}_{10} \mathrm{~N}_{2} \mathrm{BrCl} \cdot \mathrm{HCl} \cdot \mathrm{CHCl}_{3}\right) \mathrm{C}, \mathrm{H}, \mathrm{N}$.

7-Bromo-2-fluorocryptolepine Hydrochloride (11l). The title compound was prepared as above from $\mathbf{6 b}(23 \mathrm{mmol}, 6.84$ g) and $7 \mathbf{g}(23 \mathrm{mmol}, 3.80 \mathrm{~g})$. Yellow crystals, yield $13.0 \% .{ }^{1} \mathrm{H}$ $\mathrm{NMR}$ of free base $\left(\mathrm{CDCl}_{3}, \delta\right): 4.70\left(3 \mathrm{H}, \mathrm{s}, \mathrm{NCH}_{3}\right), 7.62(2 \mathrm{H}$, $\mathrm{m}, 3-H, 4-H), 7.74(1 \mathrm{H}, \mathrm{d}, J=10,9-\mathrm{H}), 7.85(1 \mathrm{H}, \mathrm{dd}, J=2.8$, $8.5 \mathrm{~Hz}, 1-H), 8.16$ ( $1 \mathrm{H}, \mathrm{dd}, J=4.3,9.5,8-H), 8.35$ (1H, s, 6-H), $8.79(1 \mathrm{H}, \mathrm{s}, 11-\mathrm{H})$. MS (EI, $\mathrm{m} / \mathrm{z}$, relative intensity, \%) $330(37)$ $\left[\mathrm{M}^{+}\right], 328(33)\left[\mathrm{M}^{+}\right], 316(98), 314$ (100), 235 (48), 208 (23), 158 (18), 118 (20). Anal. $\left(\mathrm{C}_{16} \mathrm{H}_{10} \mathrm{~N}_{2} \mathrm{BrF} \cdot \mathrm{HCl} \cdot 2.5 \mathrm{H}_{2} \mathrm{O}\right) \mathrm{C}, \mathrm{H}, \mathrm{N}$.

7-Bromo-3-chlorocryptolepine Hydrochloride (11m). The title compound was prepared as above from $\mathbf{6 b}(23 \mathrm{mmol}$, $6.84 \mathrm{~g})$ and $\mathbf{7 d}(23 \mathrm{mmol}, 4.18 \mathrm{~g})$. Yellow crystals, yield $13.0 \%$. ${ }^{1} \mathrm{H}$ NMR of free base $\left(\mathrm{CDCl}_{3}, \delta\right): 4.71\left(3 \mathrm{H}, \mathrm{s}, \mathrm{NCH}_{3}\right), 7.55(2 \mathrm{H}$, d, $8-H, 9-H), 7.70(1 \mathrm{H}, \mathrm{d}, J=8.9 \mathrm{~Hz}, 1-H), 8.10(2 \mathrm{H}, \mathrm{m}, 2-H$, $4-H$ or $6-H), 8.30(1 \mathrm{H}, \mathrm{s}, 4-H$ or $6-H), 8.80(1 \mathrm{H}, \mathrm{s}, 11-H)$. MS $\left(\mathrm{EI}, \mathrm{m} / z\right.$, relative intensity, \%) $346(100)\left[\mathrm{M}^{+}\right], 344(30)\left[\mathrm{M}^{+}\right]$, 332 (100), 330 (79), 251 (25), 216 (15), 142 (37), 108 (11). Anal. $\left(\mathrm{C}_{16} \mathrm{H}_{10} \mathrm{~N}_{2} \mathrm{BrCl} \cdot \mathrm{HCl} \cdot 0.3 \mathrm{C}_{2} \mathrm{H}_{5} \mathrm{COOCH}_{3}\right) \mathrm{C}, \mathrm{H}, \mathrm{N}$. 
7-Bromo-3-methylcryptolepine Hydrochloride (11n). The title compound was prepared as above from $\mathbf{6 b}(23 \mathrm{mmol}$, $6.84 \mathrm{~g})$ and $\mathbf{7 j}$ (23 mmol, $3.70 \mathrm{~g})$. Brown crystals, yield $10.0 \%$. ${ }^{1} \mathrm{H}$ NMR of free base $\left(\mathrm{CDCl}_{3}, \delta\right): 2.72\left(3 \mathrm{H}, \mathrm{s}, 3-\mathrm{CH}_{3}\right), 4.70(3 \mathrm{H}$, $\left.\mathrm{s}, \mathrm{NCH}_{3}\right), 7.47(1 \mathrm{H}, \mathrm{d}, J=9.2,1-\mathrm{H}$ or $2-H), 7.48(1 \mathrm{H}, \mathrm{d}, J=$ $8.4 \mathrm{~Hz}, 9-H), 7.64(1 \mathrm{H}, \mathrm{d}, J=9.2 \mathrm{~Hz}, 1-H$ or $2-H), 7.88(1 \mathrm{H}, \mathrm{s}$, $4-H), 8.02(1 \mathrm{H}, \mathrm{d}, J=8.4 \mathrm{~Hz}, 8-H), 8.23(1 \mathrm{H}, \mathrm{s}, 6-H), 8.78(1 \mathrm{H}$, $\mathrm{s}, 11-H)$. MS (EI, $m / z$, relative intensity, \%) 326, $324(100)\left[\mathrm{M}^{+}\right]$, 311, 309 (26), 229 (7), 230 (5). Anal. $\left(\mathrm{C}_{17} \mathrm{H}_{13} \mathrm{~N}_{2} \mathrm{Br} \cdot 1.6 \mathrm{HCl}\right) \mathrm{C}$, $\mathrm{N}$; H: calcd, 3.81; found 4.31 .

2,8-Dichlorocryptolepine Hydrochloride (11o). The title compound was prepared as above from $\mathbf{6 c}(23 \mathrm{mmol}, 6.11$ g) and $7 \mathbf{b}(23 \mathrm{mmol}, 4.18 \mathrm{~g})$. Yellow crystals, yield $15 \% .{ }^{1} \mathrm{H}$ NMR of free base $\left(\mathrm{CDCl}_{3}, \delta\right): 4.76\left(3 \mathrm{H}, \mathrm{s}, \mathrm{NCH}_{3}\right), 6.98(1 \mathrm{H}$, $\mathrm{dd}, J=1.9,9.0 \mathrm{~Hz}, 3-H$ or $7-H), 7.70(1 \mathrm{H}, \mathrm{d}, J=2.2 \mathrm{~Hz}, 1-H$ or $9-H), 7.74(1 \mathrm{H}, \mathrm{dd}, J=2.5,6.9 \mathrm{~Hz}, 3-H$ or $7-H), 8.50(2 \mathrm{H}$, $\mathrm{d}, J=9.7 \mathrm{~Hz}, 4-H$ and $6-H), 8.10(1 \mathrm{H}, \mathrm{d}, J=2.5 \mathrm{~Hz}, 1-H$ or $9-$ $H), 8.70(1 \mathrm{H}, \mathrm{s}, 11-H)$. MS (EI, $\mathrm{m} / z$, relative intensity, \%) 301 (100) $\left[\mathrm{M}^{+}\right], 286$ (13), 284 (20), 264 (6), 215 (4), 150 (5), 123 (7). Anal. $\left(\mathrm{C}_{16} \mathrm{H}_{10} \mathrm{~N}_{2} \mathrm{Cl}_{2} \cdot 1.4 \mathrm{HCl}\right) \mathrm{C}, \mathrm{H}, \mathrm{N}$.

2-Bromo-7-nitrocryptolepine Hydrochloride (13). Compound 12 (1 g, $2.88 \mathrm{mmol})$ was dissolved in $40 \mathrm{~mL}$ of nitric acid (69\%):glacial acetic acid (1:1) and stirred at room temperature for $24 \mathrm{~h}$. The reaction mixture was cooled on ice, basified with strong sodium hydroxide solution, and filtered. The dried product was column-chromatographed and converted to the hydrochloride salt as above. Yellow crystals, yield $13.0 \%$. ${ }^{1} \mathrm{H} \mathrm{NMR},\left(\mathrm{CF}_{3} \mathrm{COOD}, \delta\right): 4.93\left(3 \mathrm{H}, \mathrm{s}, \mathrm{NCH}_{3}\right), 8.06(1 \mathrm{H}, \mathrm{d}, J=$ $8.1 \mathrm{~Hz}, 9-H), 8.38(1 \mathrm{H}, \mathrm{d}, J=10.8 \mathrm{~Hz}, 4-H), 8.46(1 \mathrm{H}, \mathrm{d}, J=$ $10.8,3-H), 8.64(1 \mathrm{H}, \mathrm{s}, 1-H), 8.90(1 \mathrm{H}, \mathrm{d}, J=8.1 \mathrm{~Hz}, 8-H) 9.16$ $(1 \mathrm{H}, \mathrm{s}, 11-H), 9.71(1 \mathrm{H}, \mathrm{s}, 6-H)$. MS $(\mathrm{EI}, \mathrm{m} / z$, relative intensity, \%) 357, 355 (100) $\left[\mathrm{M}^{+}\right], 342,340$ (12), 327, 325 (20), 311, 309 (35), 230 (54), 229 (48), 158 (18), 118 (20). Anal. $\left(\mathrm{C}_{16} \mathrm{H}_{10} \mathrm{~N}_{3} \mathrm{O}_{2^{-}}\right.$ $\mathrm{Br} \cdot \mathrm{HCl}) \mathrm{H}, \mathrm{N}$; C: calcd, 48.9; found 51.2.

Antiplasmodial Assay. P. falciparum strain K1 was kindly supplied by Professor D. C. Warhurst (London School of Hygiene and Tropical Medicine). Malaria parasites were maintained in human A+ erythrocytes suspended in RPMI 1640 medium supplemented with $\mathrm{A}+$ serum and D-glucose according to the methods of Trager and Jensen $(1976)^{19}$ and Fairlamb et al. (1985). ${ }^{20}$ Cultures containing predominantly early ring stages were used for testing. Compounds were dissolved or micronized in DMSO and further diluted with RPMI 1640 medium (the final DMSO concentration did not exceed $0.5 \%$ which did not affect parasite growth). Two-fold serial dilutions were made in 96-well microtiter plates in duplicate, and infected erythrocytes were added to give a final volume of $100 \mu \mathrm{L}$ with $2.5 \%$ hematocrit and $1 \%$ parasitemia. Chloroquine diphosphate was used as a positive control, and uninfected and infected erythrocytes without compounds were included in each test. Plates were placed into a modular incubator gassed with 93\% nitrogen, 3\% oxygen, and $4 \%$ carbon dioxide and incubated at $37^{\circ} \mathrm{C}$ for $48 \mathrm{~h}$. Parasite growth was assessed by measuring lactate dehydrogenase activity as described by Makler et al., 1993. ${ }^{21}$ The reagent used contained the following in each $\mathrm{mL}$ acetylpyridine adenine dinucleotide (APAD), $0.74 \mathrm{mg}$; lithium lactate, $19.2 \mathrm{mg}$; diaphorase, $0.1 \mathrm{mg}$; Triton X-100, $2 \mu \mathrm{L}$; nitroblue tetrazolium, $1 \mathrm{mg}$; and phenazine ethosulfate, $0.5 \mathrm{mg}$. Fifty microliters of this reagent was added to each well and mixed, and plates were incubated for $15 \mathrm{~min}$ at $37{ }^{\circ} \mathrm{C}$. Optical densities were read at $550 \mathrm{~nm}$ using a Dynatech Laboratories MRX microplate reader, and percent inhibition of growth was calculated by comparison with control values. $\mathrm{IC}_{50}$ values were determined using linear regression analysis (Microsoft Excel). A minimum of three separate determinations was carried out for each compound.

In Vivo Antimalarial Test. This was carried out using Peters's 4-day suppressive test against $P$. berghei infection in mice. ${ }^{11}$ Female BALB/C mice, weight $18-20$ g, were inoculated with $P$. berghei (ANKA); each mouse received $1 \times 10^{7}$ infected erythrocytes by iv injection. Drugs were administered by ip injection in $0.2 \mathrm{~mL}$ of inoculum daily for four consecutive days. Control and test groups all contained five mice. On day 5 of the test a blood smear was taken, and the animals were killed.
The percent suppression of parasitemia was calculated for each dose level by comparing the parasitemias present in infected controls with those of test animals; survival times were recorded, taken as the number of days before the animals showed signs of illness due to malaria. Chloroquine diphosphate was used as a positive control.

Cytotoxicity Assay. MAC15A (murine adenocarcinoma of the colon) cells were available in our laboratory. Cells were routinely maintained as monolayer cultures in RPMI1640 culture medium supplemented with foetal calf serum (10\%), sodium pyruvate $(1 \mathrm{mM})$, L-glutamine $(2 \mathrm{mM})$, and penicillin/ streptomycin (50 IU mL $\mathrm{mL}^{-1 / 50 \mu \mathrm{g} \mathrm{mL}} \mathrm{mL}^{-1}$, and buffered with HEPES (25 mM). Chemosensitivity was assessed using the MTT assay. ${ }^{22}$ Briefly, $2 \times 10^{3}$ cells were inoculated into each well of a 96 -well plate and incubated overnight at $37^{\circ} \mathrm{C}$ in an humidified atmosphere containing $5 \% \mathrm{CO}_{2}$. All drugs were dissolved in DMSO and then diluted in culture medium to give a broad range of concentrations; the maximum DMSO concentration in any well was $0.1 \%$ shown not to affect cell growth. Medium was removed from each well and replaced with drug solutions (eight wells per drug concentration), and the plates were then incubated for a further $96 \mathrm{~h}$ before cell survival was determined. Culture medium was replaced with fresh medium $(180 \mu \mathrm{L})$ prior to the addition of $20 \mu \mathrm{L}$ of MTT solution $(0.5$ $\mathrm{mg} \mathrm{mL}{ }^{-1}$ ). Following $24 \mathrm{~h}$ incubation at $37^{\circ} \mathrm{C}$, medium plus MTT was removed from each well and the formazan crystals were dissolved in DMSO (150 $\mu \mathrm{L} /$ well). Absorbances of the resulting solutions were read at $550 \mathrm{~nm}$ and cell survival was calculated as the absorbance of treated cells divided by the control (RPMI medium plus $0.1 \%$ DMSO). Results were expressed in terms of the $\mathrm{IC}_{50}$ values (i.e. concentration of drug required to kill $50 \%$ cells), and all experiments were performed in triplicate.

Determination of $\mathbf{p} \boldsymbol{K}_{\mathrm{a}}$ Values. Acid dissociation constants were determined spectrophotometrically using a HewlettPackard HP8451A diode-array UV spectrophotometer. UV spectra of each compound $\left(0.05 \mathrm{mg} \mathrm{mL}^{-1}\right)$ dissolved in buffers of varying $\mathrm{pH}$ values ranging from 5.8 to 13.0 as well as in $0.1 \mathrm{M} \mathrm{NaOH}$ and $0.1 \mathrm{M} \mathrm{HCl}$ to ensure that the maximum and minimum absorbances of the main peak $\left(\lambda_{\max }\right)$ were determined. A minimum of seven buffer solutions was used for each compound. For buffers of $\mathrm{pH}$ 5.8-8.0 Clark and Lub's phosphate buffer $\left(\mathrm{KH}_{2} \mathrm{PO}_{4} / \mathrm{NaOH}\right) 0.1 \mathrm{M}$ was used and for $\mathrm{pH}$ 8.413.0 Sorensen's glycine I buffer $0.1 \mathrm{M}$ was employed. ${ }^{23}$ From a plot of $\mathrm{pH}$ against the absorbance of $\lambda_{\max }$, the $\mathrm{pH}$ corresponding to the midpoint between the maximum and minimum absorbance of $\lambda_{\max }$ ( $\mathrm{p} K_{\mathrm{a}}$ value) was determined. Two separate experiments were carried out for each compound.

Determination of Inhibition of $\beta$-Hematin Formation. The quantitative BHIA ( $\beta$-hematin inhibitory activity) assay is based on the differential solubility of hemin and $\beta$-hematin in DMSO and $\mathrm{NaOH}$ solution, respectively. ${ }^{24}$ The method determines a $50 \%$ inhibitory concentration for $\beta$-hematin inhibition in equivalents of the compound under test with respect to hemin $\left(\mathrm{BHIA}_{50}\right)$. A total of $50 \mu \mathrm{L}$ of an $8 \mathrm{mM}$ solution of hemin was dissolved in DMSO and distributed into 96-well U-bottom microplates $(0.4 \mu \mathrm{mol} / \mathrm{well}) ; 50 \mu \mathrm{L}$ of different compounds in water, in doses from 0.25 to 2 (or 4 if they were soluble) molar equivalents to hemin, were added to triplicate test wells. In control wells, $50 \mu \mathrm{L}$ of water was added. Waterinsoluble compounds were solubilized in $25 \mu \mathrm{L}$ of DMSO and then added to hemin prepared at $16 \mathrm{mM}$ and distributed into the wells in $25 \mu \mathrm{L}$ aliquots. The final concentration of DMSO/ well was kept constant at $25 \%$. $\beta$-Hematin formation was initiated by the addition of $100 \mu \mathrm{L}$ of $8 \mathrm{M}$ acetate buffer $(\mathrm{pH}$ 5.0 ), and the plates were then incubated at $37{ }^{\circ} \mathrm{C}$ for $18 \mathrm{~h}$. Following centrifugation to isolate DMSO-insoluble $\beta$-hematin, the product was dissolved in $0.1 \mathrm{M} \mathrm{NaOH}$ solution and determined spectrophotometrically at $405 \mathrm{~nm}$ as previously described. ${ }^{24,15}$

Acknowledgment. We are most grateful to Dr. Brian Goodwin and Professor Vivette Glover, Imperial 
College, University of London, for the generous provision of isatin derivatives. We are grateful to Mr. Andrew Healy for running mass spectra and Dr. Richard Wheelhouse for help with NMR experiments. Professor Tim Egan, University of Cape Town. is kindly acknowledged for his helpful advice and comments. M.F.-H. thanks Ahwaz University of Medical Sciences for financial support.

\section{References}

(1) Fidock, D. A.; Rosenthal, P. J.; Croft, S. L.; Brun, R.; Nwaka, S. Antimalarial drug discovery: Efficacy models for compound screening. Nat. Rev. Drug Discovery 2004, 3, 509-520.

(2) Boye, G. L.; Ampofo, O. Clinical uses of Cryptolepis sanguinolenta. Proceedings of the First International Seminar on Cryptolepine, July 27-30, 1983; University of Science and Technology: Kumasi, Ghana, 1983; pp 37-40.

(3) Wright, C. W.; Addae-Kyereme, J.; Breen, A. G.; Brown, J. E.; Cox, M. F. et al. Synthesis and evaluation of cryptolepine analogues for their potential as new antimalarial agents. J. Med. Chem. 2001, 44, 3187-3194.

(4) Lisgarten, J. N.; Coll, M.; Portugal, J.; Wright, C. W.; Aymami, $\mathrm{J}$. The antimalarial and cytotoxic drug cryptolepine intercalates into DNA at cytosine-cytosine sites. Nat. Struct. Biol. 2002, 9, $57-60$.

(5) Bonjean, K.; De Pauw-Gillet, M. C.; Defresne, M. P.; Colson, P.; Houssier, C. et al. The DNA intercalating alkaloid cryptolepine interferes with topoisomerase II and inhibits primarily DNA synthesis in B16 melanoma cells. Biochemistry 1998, 37, 51365146 .

(6) Kaschula, C. H.; Egan, T. J.; Hunter, R.; Basilico, N.; Parapini, $\mathrm{S}$. et al. Structure-activity relationships in 4-aminoquinoline antiplasmodials. The role of the group at the 7-position. J. Med. Chem. 2002, 45, 3531-3539.

(7) Pagola, S.; Stephens, P. W.; Bohle, D. S.; Kosar, A. D.; Madsen, $\mathrm{S}$. K. The structure of malaria pigment beta-haematin. Nature 2000, 404, 307-310.

(8) Egan, T. J.; Ross, D.; Adams, P. A. Quinoline anti-malarial drugs inhibit spontaneous formation of $\beta$-haematin (malaria pigment). FEBS Lett. 1994, 352, 54-57.

(9) Raileanu, D.; Constantinescu-Simon, O.; Mosanu, E.; Nenitzescu, C. D. Improved preparatory method for N,O-diacetylindoxyl and $N$-acetylindoxyl. Rev. Rom. Chim. 1967, 12, 105-108.

(10) Holt, S. J.; Petrow, V. Carbazoles, carbolines, and related compounds. Part 1. J. Chem. Soc. 1947, 607-611.
(11) Peters, W.; Portus, J. H.; Robinson, B. L. The chemotherapy of rhodent malaria XXII. The value of drug resistant strains of Plasmodium berghei in screening for blood schizontocidal activity. Ann. Trop. Med. Parasitol. 1975, 69, 155-171.

(12) Krogstad, D. J.; Dibyendu, D. Chloroquine: modes of action and resistance and the activity of chloroquine analogs. Malaria; ASM Press: Washington, D.C., 1998; pp 331-339.

(13) Arzel, E.; Rocca, P.; Grellier, P.; Labaeid, M.; Frappier, F. et al. New synthesis of benzo-delta-carbolines, cryptolepines, and their salts: In vitro cytotoxic, antiplasmodial, and antitrypanosoma activities of delta-carbolines, benzo-delta- carbolines, and cryptolepines. J. Med. Chem. 2001, 44, 949-960.

(14) Sandmeyer, T. Uberisonitrosacetanilide und deren Kondensation zu Isatinen. Helvetica Chimica Acta 1919, 2, 234-242.

(15) Marvel, C. S.; Hiers, G. S. Isatin. In: Blatt, A. H. Ed. Organic Syntheses Collective; Wiley: New York, 1941; pp 327-330.

(16) Goodwin, B. L. Hazardous reactions. Chem. Br. 1988, 24, 336

(17) Gandy, R.; Hill, M. G. Hazardous reactions. Chem. Br. 1988, 24,336

(18) Sadler, P. W. Separation of isomeric isatins. J. Org. Chem. 1956 , $21,169-170$.

(19) Trager, W.; Jensen, J. B. Human malaria parasites in continuous culture. Science 1976, 193, 673.

(20) Fairlamb, A. H.; Warhurst, D. C.; Peters, W. An Improved Technique for the Cultivation of Plasmodium falciparum In vitro without Daily Medium Change. Ann. Trop. Med. Parasitol. 1985, 79, 379-384.

(21) Makler, M. T.; Ries, J. M.; Williams, J. A.; Bancroft, J. E.; Piper, R. C. et al. Parasite Lactate-Dehydrogenase as an Assay for Plasmodium falciparum Drug-Sensitivity. Am. J. Trop. Med. Hyg. 1993, 48, 739-741.

(22) Mosmann, T. Rapid Colorimetric Assay for Cellular Growth and Survival - Application to Proliferation and Cyto-Toxicity Assays. J. Immun. Methods 1983, 65, 55-63.

(23) Diem, K. Documenta Geigy. Scientific tables; Geigy Pharmaceuticals Company Limited: Manchester, 1962.

(24) Basilico, N.; Pagani, E.; Monti, D.; Olliaro, P.; Taramelli, D. A microtitre-based method for measuring the haem polymerisation inhibitory activity (HPIA) of antimalarial drugs. J. Antimicrob. Chemother. 1998, 42, 55-60.

(25) Parapini, S.; Basilico, N.; Pasini, E.; Egan, T. J.; Olliaro, P.; Taramelli, D.; Monti, D. Standardisation of the physicochemical parameters to assess in vitro the beta-hematin inhibitory activity of antimalarial drugs. Exp. Parasitol. 2000, 96, 249-256.

JM040893W 